\title{
Fermentabilitas ruminal secara in vitro suplementasi tepung daun gamal, kelor, randu dan sengon dalam konsentrat hijau
}

\section{Ruminal fermentability in vitro supplementation Gliricidia sepium, Moringa oleifera Lamk, Ceiba pentandra and Paraserianthes falcataria leaf meal in green concentrate}

\author{
Eko Marhaeniyanto* dan Sri Susanti \\ Universitas Tribhuwana Tunggadewi \\ Jalan Telaga Warna Blok C, Tlogomas, Malang, Jawa Timur \\ Submitted: 19 Februari 2018, Accepted: 16 September 2018
}

\begin{abstract}
ABSTRAK: Penelitian bertujuan untuk mempelajari fermentabilitas ruminal secara in vitro suplementasi tepung daun gamal, kelor, randu dan sengon dalam pakan konsentrat yang akan diujikan pada domba. Penelitian dilaksanakan dengan metode percobaan, menggunakan Rancangan Acak Kelompok (RAK) 6 perlakuan dan 3 kelompok. Pakan perlakuan yang diuji terdiri dari konsentrat tanpa daun dan konsentrat dengan suplementasi tepung daun. Kadar protein kasar (PK) konsentrat disusun $16 \%, 18 \%$ dan $20 \%$. Suplementasi menggunakan campuran tepung daun gamal, kelor, randu dan sengon $(1: 1: 1: 1)$ sebanyak $10 \%, 20 \%$ dan $30 \%$.Variabel yang diukur adalah kecernaan bahan kering $(\mathrm{KcBK})$ dan bahan organik (KcBO) inkubasi 48 jam, laju produksi gas, biomassa mikroba dan kadar $\mathrm{NH}_{3}$. Penggunaan campuran tepung daun dalam pakan konsentrat menghasilkan KcBK secara in-vitro sama baik dengan pakan konsentrat tanpa suplementasi daun. Suplementasi tepung daun sebanyak $30 \%$ dengan kadar PK konsentrat 20\% menghasilkan penurunan nilai fermentabilitas. Suplementasi tepung daun sebanyak 20\% dalam pakan konsentrat dengan PK 18\% menghasilkan nilai fermentabilitas terbaik. Perlu penelitian lanjut uji coba secara in-vivo pada ternak domba penggunaan pakan konsentrat protein $18 \%$ dengan memanfaatkan tepung daun gamal, kelor, randu dan sengon sebagai sumber protein murah.
\end{abstract}

Kata kunci : konsentrat hijau; tepung daun; fermentabilitas.

ABSTRACT: The aim of this research was to study the in vitro ruminal fermentability of supplementation of Gliricidia sepium, Moringa oleifera, Lamk (MOL), Ceiba pentandra and Paraserianthes falcataria leaf meal in concentrate feed to be tested on sheep. This research with the experimental methods was arranged in Randomized Block Design (RBD) with 6 treatments and 3 groups. The treatment feed tested consisted of concentrate without leaves and concentrate with leaf meal supplementation. Crude protein content (CP) concentrates were prepared $16 \%, 18 \%$ and $20 \%$. Supplementation uses a mixture of Gliricidia sepium, MOL, Ceiba pentandra and Paraserianthes falcataria leaf meal in concentrate feed (1:1:1:1) as much as 10\%, 20\% and $30 \%$. The measured variables were degradation of dry matter (DDM) and degradation of organic matter (DOM), gas production rate, microbial biomass and $\mathrm{NH}_{3}$ concentration. The use of mixed leaf meal in concentrate feed resulted in in vitro DDM as well as concentrate feed without leaf meal supplementation. Supplementation of leaf meal in concentrate feed as much as 30\% with CP $20 \%$ resulted in a decrease in the value of fermentability. The supplementation of leaf meal in concentrate feed as much as $20 \%$ in concentrate feed with CP $18 \%$ produced the best fermentability value. Suggested for in-vivo trials on sheep using $18 \%$ protein concentrate feed by utilizing Gliricidia sepium, MOL, Ceiba pentandra and Paraserianthes falcataria leaf meal in concentrate feed as cheap protein sources.

Keyword: green concentrate; mixed leaf meal; fermentability in vitro

*Corresponding Author: marhaeniyanto@unitri.ac.id

DOI: 10.21776/ub.jiip.2018.028.03.04 


\section{PENDAHULUAN}

Daun tanaman bermanfaat bagi ternak karena memiliki keunggulan kandungan nutrient yang dibutuhkan oleh ternak. Formulasi konsentrat hijau berbasis daun tanaman memungkinkan menggunakan sumber protein dari beberapa daun tanaman pohon. Cheeke (2000) telah melakukan kajian pada beberapa daun tanaman yang mengandung senyawa sekunder tannin dan saponin. Penelitian penggunaan daun tanaman yang memiliki kandungan protein lebih dari $18 \%$ sebagai bahan penyusun pakan konsentrat telah peneliti lakukan mulai tahun 2010 dimaksudkan untuk mendapatkan pakan yang murah, berkualitas dan berkelanjutan. Maw et al., (2006), menyatakan bahwa daun tanaman umumnya mengandung senyawa sekunder tannin dan saponin yang keberadaannya bila tidak melebihi ambang batas akan bermanfaat bagi ternak ruminansia. Penambahan tanin pada pakan protein tinggi dapat menurunkan degradasi karbohidrat struktural dan gas metana yang dihasilkan.

Sementara itu saponin yang terkandung dalam daun tanaman berperan sebagai defaunating agents terhadap populasi protozoa sehingga biosintesa protein mikroba termasuk populasi bakteri akan meningkat. (Santoso, 2005; Santoso dan Hariadi, 2007). Saponin dari daun tanaman juga dilaporkan mampu meningkatkan efisiensi proses fermentasi melalui mekanisme penurunan populasi protozoa di dalam rumenyaitu dengan menurunkan sifat predator protozoa terhadap bakteri (Holtshausen et al., 2009). Penurunan populasi protozoa rumen mengakibatkan populasi bakteri meningkat, dan semakin kecilnya turnover protein di dalam rumen mengakibatkan jumlah protein mikroba yang ke duodenum meningkat (Cheeke, 2000; Hess et al., 2006).

Dalam penelitian ini diuji secara in vitro penggunaan kombinasi tepung daun Gamal (Gliricidia sepium), Kelor (Moringa oleifera, Lamk), Randu (Ceiba pentandra) dan Sengon (Paraserianthes falcataria) dengan perbandingan 1:1:1:1 sebanyak 10, 20 dan 30\% dalam pakan konsentrat dengan protein kasar (PK) 16\%, 18\% dan $20 \%$. Penggunaan kombinasi tepung daun dalam pakan konsentrat ini melanjutkan penelitian Susanti dan Marhaeniyanto (2015), bahwa daun tanaman yang diteliti banyak tersedia dan biasa digunakan peternak pada lokasi dan ketinggian berbeda di wilayah Malang Raya. Penelitian terdahulu Marhaeniyanto (2014) uji in-vivo suplementasi penggunaan daun sebanyak $30 \%$ dalam pakan konsentrat dengan PK 14\% dan $18 \%$ pada domba menghasilkan penampilan terbaik pada domba dengan perlakuan PK $18 \%$.

Pada penelitian ini penggunaan kombinasi tepung daun dari 10 hingga $30 \%$ dalam konsentrat berkonsekuensi pada meningkatnya kandungan PK konsentrat sebesar $16 \%$, $18 \%$ dan $20 \%$. Suplementasi tepung daun tanaman dalam pakan konsentrat ini (selanjutnya disebut sebagai konsentrat hijau) diharapkan masih menghasilkan proses fermentasi normal dalam rumen ternak ruminansia. Disamping itu terkait dengan implementasi di lapangan, penggunaan kombinasi tepung daun 10-30\% dengan PK 16-20\% diharapkan dapat menghasilkan pakan konsentrat yang berkualitas dengan harga yang relatif terjangkau karena memanfaatkan bahan baku lokal asal daun tanaman.

Penelitian ini merupakan penelitian awal untuk menguji secara in-vitro suplementasi daun gamal, kelor, randu dan 
sengon dalam konsentrat hijau, disusun untuk memenuhi kebutuhan ternak ruminansia khususnya domba. Hasil penelitian diharapkan bisa memberikan informasi tentang hasil fermentasi pakan secara in vitro dari konsentrat hijau yang disuplementasi dengan tepung daun gamal, kelor, randu dan sengon. Hasil terbaik akan dipergunakan sebagai salah satu dasar pertimbangan formulasi konsentrat berbasis daun tanaman untuk uji in vivo pada ternak domba.

\section{MATERI DAN METODE}

Penelitian ini merupakan bagian dari rangkaian penelitian tentang pakan konsentrat berbasis daun tanaman. Materi penelitian daun tanaman diperoleh di sekitar Tlogomas Malang. Proses pembuatan tepung daun dilakukan di Laboratorium Lapang Fakultas Pertanian Universitas Tribhuwana Tunggadewi. Pengujian in vitro dan analisis proksimat dilakukan di Laboratorium Nutrisi Fakultas Peternakan Universitas Brawijaya Malang.

Uji in vitro dilakukan pada pakan konsentrat dengan kandungan protein yang berbeda $(16 \%, 18 \%, 20 \%)$ baik tanpa tepung daun ataupun dengan penggunaan tepung daun tanaman $(10 \%, 20 \%$ dan $30 \%)$. Tepung daun terdiri dari campuran daun Gamal, Kelor, Randu dan Sengon dengan perbandingan (1:1:1:1). Percobaan terdiri dari 6 perlakuan, masing-masing diulang 3 kali, dirancang menggunakan rancangan acak kelompok (RAK)

$$
\begin{aligned}
\mathrm{R}_{1}= & \text { Pakan konsentrat PK } 16 \% \text {, tan- } \\
& \text { pa campuran tepung daun } \\
\mathrm{R}_{1-\mathrm{D}}= & \text { Pakan konsentrat PK } 16 \%, \\
& \text { dengan } 10 \% \text { campuran tepung } \\
& \text { daun } \\
\mathrm{R}_{2}= & \text { Pakan konsentrat PK } 18 \%, \text { tan- }
\end{aligned}
$$

$$
\begin{aligned}
& \text { pa campuran tepung daun } \\
\mathrm{R}_{2-\mathrm{D}}= & \text { Pakan konsentrat PK 18\%, } \\
& \text { dengan 20\% campuran tepung } \\
& \text { daun } \\
\mathrm{R}_{3}= & \text { Pakan konsentrat PK 20\%, tan- } \\
& \text { pa campuran tepung daun } \\
\mathrm{R}_{3-\mathrm{D}=}= & \text { Pakan konsentrat PK 20\%, } \\
& \text { dengan 30\% campuran tepung } \\
& \text { daun }
\end{aligned}
$$
$\mathrm{R}_{3-\mathrm{D}}=$ Pakan konsentrat PK 20\%, dengan $30 \%$ campuran tepung daun

Pada pengujian in vitro digunakan substrat basal rumput gajah dan konsentrat perlakuan dengan proporsi seperti pakan basal (1:1) yang diberikan pada ternak sapi yang dipergunakan sebagai donor cairan rumen. Masing-masing perlakuan disiapkan secara duplo dan diulang 3 kali. Variabel yang diukur meliputi: komposisi nutrien, kecernaan pakan, produksi gas, laju produksi gas, biomasa mikroba dan kadar $\mathrm{NH}_{3}$.

- Analisis proksimat (AOAC, 1990) untuk mengetahui kandungan BK, BO, PK, LK, SK dari sampel.

- Produksi gas diukur sesuai petunjuk Makkar, Blủmmel and Becker (1995). Volume gas dicatat setelah inkubasi 2, $4,6,8,10,12,14,16,18,20,24$ dan 48 jam. Volume gas bersih pada setiap periode inkubasi dihitung dengan mengurangkan volume gas dalam syringe yang mengandung substrat dan volume gas dari blank. Substrat pakan basal ditimbang $500 \mathrm{mg} \mathrm{BK}$, dimasukkan ke dasar syringe dan tidak mengotori dinding syringe. $40 \mathrm{ml}$ campuran buffer dan cairan rumen dimasukkan dalam syringe dengan menggunakan dispenser melalui ujung syringe. Kinetika produksi gas diestimasi melalui persamaan eksponensial yang dideskripsikan oleh Ørskov and McDonald (1979) 
berikut: $\mathrm{p}=\mathrm{a}+\mathrm{b}\left(1-\mathrm{e}^{-\mathrm{ct}}\right)$. Nilai $\mathrm{p}$ adalah produksi gas kumulatif pada waktu $t$ jam, sedangkan a, b dan c merupakan konstanta dari persamaan eksponensial tersebut. Konstanta dapat diinterpretasikan sebagai produksi gas dari fraksi yang mudah larut (a), produksi gas dari fraksi yang tidak larut namun dapat difermentasikan (b) dan laju reaksi pembentukan gas (c), dengan demikian $a+b$ dapat diartikan sebagai produksi gas maksimum yang dapat terbentuk selama proses fermentasi pada waktu $\mathrm{t}$ mendekati tak hingga. Penghitungan konstanta persamaan eksponensial dilakukan dengan curve fitting program pada MS. Excel menggunakan metode neway.

- Perhitungan kecernaan selama 2 x 48 jam. Setelah masa inkubasi 2 x 48 jam, residu disaring dengan krusibel Gooch kemudian dianalisis kandungan BK, BO. Bahan yang hilang merupakan komponen yang tercerna, sedangkan yang tersisa adalah bahan-bahan yang tidak tercerna (undigested materials).

- Penentuan biomasa mikroba dilakukan menurut petunjuk Blummel et. al., (1997). Biomasa mikroba = Apparent undegradable-True undegradable Apparent Undegradable diperoleh dengan cara : setelah waktu inkubasi 48 jam, 3 buah syringe direndam dalam air es untuk menghentikan proses fermentasi, selama lebih kurang 4 jam sebelum dicentrifuge. Isi syringe dikeluarkan seluruhnya lalu dipusingkan $10.000 \mathrm{rpm}$ selama 16 menit. Residu yang diperoleh dioven $105^{\circ} \mathrm{C}$ selama semalam, kemudian dimasukkan eksikator selama 1 jam dan selanjutnya ditimbang. Berat yang diperoleh adalah Apparent
Undegradable True Undegradable diperoleh dengan cara: perebusan isi syringe setelah inkubasi 48 jam, dengan $100 \mathrm{ml}$ larutan NDS sampai mendidih selama 1 jam. Residu disaring dengan crucible yang telah ditimbang beratnya, dicuci dengan air panas 5 kali dan dengan aceton 3 kali. Setelah bau aceton hilang crucible dioven $105^{\circ} \mathrm{C}$ selama semalam, didinginkan dalam eksikator selama 1 jam kemudian ditimbang. Berat yang diperoleh adalah True Undegradable.

- Pengukuran kadar $\mathrm{N}-\mathrm{NH}_{3}$ cairan rumen dilakukan menurut petunjuk Conway (1957). Pengamatan dilakukan pada sampel cairan rumen dalam syringe dengan waktu pengamatan 4, 12 dan 24 jam masa inkubasi.

Hasil penelitian berupa data (1) Komposisi nutrien $\mathrm{BK}, \mathrm{BO}, \mathrm{PK}, \mathrm{LK}, \mathrm{SK}$, (2) kecernaan $\mathrm{BK}$ dan kecernaan $\mathrm{BO}$ in vitro (3) produksi gas kumulatif, (4) biomasa mikroba (5) kadar $\mathrm{NH}_{3}$, dianalisis menggunakan program Excel 2007 dan SPSS 16. Uji lanjut Beda Nyata Jujur (Yitnosumarto, 1993).

\section{HASIL DAN PEMBAHASAN}

Komposisi kimia bahan pakan dan konsentrat perlakuan disajikan pada Tabel 1. Memperhatikan hasil analisis pada Tabel 1. Tampak bahwa kandungan PK yang tinggi pada daun berpotensi untuk dimanfaatkan sebagai sumber suplemen protein dalam pakan ternak ruminansia. Penggunaan campuran tepung daun gamal, kelor, randu dan sengon (1:1:1:1) sebanyak 10, 20 dan $30 \%$ dalam konsentrat berkontribusi terhadap peningkatan kadar protein pakan perlakuan. Pakan perlakuan yang mampu menghasilkan produk fermentasi secara normal secara in vitro akan diteliti lebih lanjut secara in vivo. 
Tabel 1. Komposisi kimia bahan pakan dan konsentrat perlakuan

\begin{tabular}{lrrrr}
\hline Nama sampel & BK $(\%)$ & BO $(\%)$ & PK $(\%)$ & SK $(\%)$ \\
\hline Bahan pakan: & & & & \\
Daun gamal & 21,63 & 89,73 & 22,65 & 16,31 \\
Daun kelor & 18,43 & 85,02 & 28,43 & 8,59 \\
Daun randu & 35,55 & 89,24 & 19,66 & 21,04 \\
Daun sengon & 32,19 & 91,30 & 18,35 & 16,56 \\
Pollard & 49,67 & 94,66 & 19,73 & 10,18 \\
Dedak & 88,64 & 90,98 & 9,64 & 6,42 \\
Bungkil kelapa & 86,70 & 92,14 & 21,79 & 13,29 \\
Bungkil kedelai & 86,00 & 92,00 & 41,30 & 5,30 \\
Kulit kopi & 91,17 & 90,83 & 11,18 & 21,74 \\
Tetes & 30,23 & 88,10 & 2,20 & - \\
Mineral + garam & - & - & - & - \\
Tebon jagung & 18,52 & 91,38 & 7,93 & 32,81 \\
& & & & \\
Pakan Perlakuan: & & & & \\
$\mathrm{R}_{1}$ & 90,42 & 92,02 & 15,91 & 20,76 \\
$\mathrm{R}_{1-\mathrm{D}}$ & 89,14 & 92,65 & 16,03 & 19,58 \\
$\mathrm{R}_{2}$ & 89,97 & 92,35 & 18,23 & 18,40 \\
$\mathrm{R}_{2-\mathrm{D}}$ & 91,09 & 92,04 & 18,17 & 21,01 \\
$\mathrm{R}_{3}$ & 90,78 & 92,13 & 20,04 & 19,91 \\
$\mathrm{R}_{3-\mathrm{D}}$ & 90,33 & 92,09 & 20,06 & 18,82 \\
\hline
\end{tabular}

Kecernaan BK dan BO dapat digunakan sebagai salah satu indikator untuk menentukan kualitas pakan. Nilai kecernaan BK dan BO menunjukkan seberapa besar zat makanan dalam bahan pakan dapat dimanfaatkan oleh mikroba rumen serta manfaat yang diberikan pada ternak. Kecernaan BK dan kecernaan BO in vitro dari konsentrat perlakuan disajikan pada Tabel 2. Kecernaan BK antar perlakuan tidak berbeda nyata, karena pakan perlakuan diformulasi dengan kandungan BK yang hampir sama. Nilai kecernaan berkaitan juga dengan kadar SK (Tillman dkk., 1998). Kadar SK pada pakan perlakuan yang diuji relatif sama berkisar pada $18,40-21,01 \%$.

Perbedaan yang sangat nyata diperoleh pada nilai kecernaan BO. Secara umum kecernaan BO pakan konsentrat tanpa daun tanaman lebih tinggi daripada konsentrat dengan suplementasi daun. Konsentrat tanpa daun lebih mudah terdegradasi karena tersusun dari bahan pakan yang mudah larut di dalam rumen (seperti pollard, dedak, bungkil kedelai dan kelapa). Pada awal inkubasi mikroba rumen mendegradasi bahan yang lebih mudah larut sehingga laju degradasinya tinggi. Suplementasi dengan tepung daun menghasilkan nilai kecernaan $\mathrm{BO}$ yang lebih rendah, diduga tepung daun memerlukan waktu lebih lama untuk dapat terdegradasi di rumen akibat keberadaan anti nutrisi condensed tannin (Jayanegara dan Sofyan, 2008). Meningkatnya kadar PK pakan pada umumnya diikuti dengan meningkatnya nilai kecernaan. Namun peningkatan PK pada perlakuan $R_{3}$ dan $R_{3}$ D ternyata menghasilkan nilai kecernaan 
BO lebih rendah daripada $\mathrm{R}_{2}$ dan $\mathrm{R}_{2-\mathrm{D}}$. Perubahan proporsi penggunaan bahan pakan untuk mencapai PK $20 \%$ pada $\mathrm{R}_{3}$, mengurangi ketersediaan bahan pakan yang memiliki kelarutan lebih tinggi. Di sisi lain meningkatnya penggunaan tepung daun pada perlakuan $\mathrm{R}_{3-\mathrm{D}}$ menyebabkan meningkatnya proteksi protein akibat keberadaan anti nutrisi CT sehingga kecernaan $\mathrm{BO}$ berkurang.

Pakan perlakuan yang diuji menghasilkan nilai kecernaan lebih dari 55\% (Preston and Leng, 1987). Hasil penelitian Muchlas, Kusmartono dan Marjuki (2013) memperoleh nilai rataan kecernaan BK dan kecernaan BO in-vitro tepung daun kelor masing-masing $56,96 \pm 1,24 \%$ dan 55,34 $\pm 3,09 \%$. Demikian pula Marhaeniyanto, Rusmiwari dan Susanti (2015) menyatakan bahwa penambahan tepung daun kelor sebanyak $10 \%$ dalam pakan konsentrat menghasilkan rataan kecernaan $\mathrm{BK}$ dan kecernaan $\mathrm{BO}$ sebesar $77,73 \pm 5,72 \%$ dan $77,84 \pm 5,59 \%$.

Peningkatan penggunaan daun dalam konsentrat menghasilkan nilai kecernaan dengan kecenderungan yang semakin menurun. Perlakuan pakan dengan kandungan daun $30 \%$ berdampak nilai kecernaan lebih rendah, ini menunjukkan bahwa pakan konsentrat relatif lebih sulit didegradasi diduga akibat keberadaan tanin dalam daun (Susanti dan Marhaeniyanto. 2011). Tanin dapat melindungi protein dari degradasi mikroba rumen, melalui terbentuknya ikatan kompleks taninprotein. Ikatan kompleks tersebut dapat lepas dan protein dicerna secara enzimatis di abomasum. Dengan demikian, keberadaan tanin dimanfaatkan untuk manipulasi protein berkualitas sehingga lebih tersedia di pencernaan pasca rumen.
Produksi gas merupakan suatu cerminan dari jumlah substrat yang terfermentasi. Produksi gas ini sangat erat kaitannya dengan produksi VFA, semakin banyak BO pakan yang diubah menjadi VFA maka gas yang dihasilkan juga semakin banyak (Makkar et al., 1995). Produksi gas pada dasarnya merupakan refleksi dari banyaknya energi yang dihasilkan dari proses fermentasi tersebut. Suplementasi campuran tepung daun dalam pakan perlakuan secara sangat nyata mempengaruhi produksi gas yang dihasilkan. Produksi gas tertinggi selama waktu inkubasi 48 jam dihasilkan oleh pakan $\mathrm{R}_{1}$ sebanyak 103,4 ml/0,5g BK. Ini menunjukkan bahwa perlakuan $\mathrm{R}_{1}$ merupakan pakan sumber energi yang mudah terdegradasi dalam rumen. Pakan $\mathrm{R}_{1}$ tanpa tambahan daun sementara bahan penyusun konsentrat yang lain (polard, dedak, bungkil kelapa, bungkil kedelai, tetes) mudah didegradasi sehingga menghasilkan produksi gas yang tinggi.

Produksi gas terrendah dihasilkan oleh pakan $\mathrm{R}_{3-\mathrm{D}}$. Produksi gas yang lebih rendah mengindikasikan bahwa BO yang didegradasi oleh mikroba lebih sedikit. Semakin rendahnya produksi gas tersebut seiring dengan meningkatnya proporsi daun di dalam komponen pakan. Rendahnya produksi gas pada $\mathrm{R}_{3-\mathrm{D}}$ didukung dengan hasil $\mathrm{KcBK}$ dan $\mathrm{KcBO}$ yang juga rendah (Tabel 2.). Tinggi atau rendahnya produksi gas yang dihasilkan bergantung pada jumlah substrat yang terdegradasi (Makkar et al., 1995).

Produksi gas 48 jam, potensial degradasi dan laju degradasi pakan perlakuan secara in vitro disajikan pada Tabel 3. Produksi gas maksimum $(\mathrm{a}+\mathrm{b})$ merupakan gambaran nilai potensial degradasi pakan. 
Perlakuan $\mathrm{R}_{1}$ menghasilkan produksi gas maksimum tertinggi, sementara perlakuan $\mathrm{R}_{1-\mathrm{D}}, \mathrm{R}_{2-\mathrm{D}}$ dan $\mathrm{R}_{3-\mathrm{D} m e n g h a s i l k a n}$ gas relatif sedikit, baik pada waktu inkubasi 48 jam maupun produksi gas maksimumnya. Produksi gas yang dihasilkan pada 48 jam inkubasi lebih dari $85 \%$ produksi gas maksimumnya pada hampir semua perlakuan. Waktu inkubasi semakin bertambah, substrat yang dapat difermentasi semakin berkurang sehingga laju produksi gas in vitrojuga berkurang (Jayanegara dan Sofyan, 2008).
Laju produksi gas terrendah dihasilkan

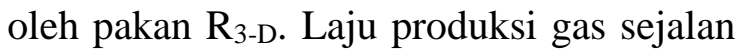
dengan nilai $\mathrm{KcBO}$ dan produksi gas yang dihasilkan. Tinggi atau rendahnya produksi gas bergantung pada jumlah substrat yang terdegradasi (Makkar et al.,1995). Semakin berkurangnya laju produksi gas didukung dengan nilai KcBO yang juga rendah. Diduga akibat meningkatnya proporsi daun di dalam komponen pakan konsentrat perlakuan.

Tabel 2. Nilai kecernaan BK(\%) dan kecernaanBO (\%)in vitro inkubasi 48 jamdari pakan perlakuan

\begin{tabular}{ccc}
\hline \multirow{2}{*}{ Pakan perlakuan } & \multicolumn{2}{c}{ Inkubasi 48 jam } \\
\cline { 2 - 3 } & Nilai kecernaan BK $(\%)$ & Nilai kecernaan BO (\%) \\
\hline $\mathrm{R}_{1}$ & $66,2 \pm 1,11^{\mathrm{a}}$ & $71,4 \pm 1,59^{\mathrm{bc}}$ \\
$\mathrm{R}_{1-\mathrm{D}}$ & $65,4 \pm 1,06^{\mathrm{a}}$ & $68,4 \pm 1,33^{\mathrm{a}}$ \\
$\mathrm{R}_{2}$ & $69,4 \pm 1,08^{\mathrm{a}}$ & $73,3 \pm 1,17^{\mathrm{c}}$ \\
$\mathrm{R}_{2-\mathrm{D}}$ & $64,7 \pm 1,52^{\mathrm{a}}$ & $68,5 \pm 1,32^{\mathrm{a}}$ \\
$\mathrm{R}_{3}$ & $64,3 \pm 0,76^{\mathrm{a}}$ & $69,5 \pm 1,65^{\mathrm{ab}}$ \\
$\mathrm{R}_{3-\mathrm{D}}$ & $64,4 \pm 0,45^{\mathrm{a}}$ & $67,4 \pm 1,03^{\mathrm{ab}}$ \\
\hline
\end{tabular}

Keterangan: ${ }^{\mathrm{a}-\mathrm{c}}$ Superskrip yang berbeda pada kolom yang sama untuk setiap variabel menunjukkan adanya perbedaan sangat nyata $(\mathrm{P}<0,01)$. $\mathrm{BK}=$ bahan kering, $\mathrm{BO}=$ bahan organik,

Tabel 3. Produksi gas total, potensial degradasi dan laju degradasi pakan perlakuan secara in vitro

\begin{tabular}{cccc}
\hline Pakan perlakuan & $\begin{array}{c}\text { Gas total } \\
\text { inkubasi 48 jam } \\
(\mathrm{ml})\end{array}$ & $\begin{array}{c}\text { Nilai a+b } \\
(\mathrm{ml})\end{array}$ & $\begin{array}{c}\text { Nilai c } \\
(\mathrm{ml} / \mathrm{jam})\end{array}$ \\
\hline $\mathrm{R}_{1}$ & $103 \pm 4,00^{\mathrm{cd}}$ & $121 \pm 5,42^{\mathrm{cd}}$ & $0,049^{\mathrm{d}}$ \\
$\mathrm{R}_{1-\mathrm{D}}$ & $98,8 \pm 3,40^{\mathrm{bc}}$ & $113 \pm 5,04^{\mathrm{bc}}$ & $0,044^{\mathrm{abc}}$ \\
$\mathrm{R}_{2}$ & $101 \pm 2,31^{\mathrm{bc}}$ & $115 \pm 3,08^{\mathrm{bc}}$ & $0,047^{\mathrm{bcd}}$ \\
$\mathrm{R}_{2-\mathrm{D}}$ & $84,6 \pm 4,63^{\mathrm{a}}$ & $102 \pm 6,35^{\mathrm{a}}$ & $0,043^{\mathrm{ab}}$ \\
$\mathrm{R}_{3}$ & $99,1 \pm 1,38^{\mathrm{bc}}$ & $115 \pm 1,75^{\mathrm{bc}}$ & $0,045^{\mathrm{abcd}}$ \\
$\mathrm{R}_{3-\mathrm{D}}$ & $94,8 \pm 4,05^{\mathrm{b}}$ & $110 \pm 4,39^{\mathrm{ab}}$ & $0,040^{\mathrm{a}}$ \\
\hline
\end{tabular}

Keterangan : $a=$ gas setelah inkubasi selama 48 jam; $a+b=$ produksi gas maksimum pada $t$ mendekati tak hingga (asimtot); c=laju produksi gas kumulatif. ${ }^{\text {a-d: }}$ Superskrip berbeda pada kolom yang sama menunjukkan berbeda sangat nyata $(\mathrm{P}<0,01)$. 
Tabel 4. Produksi biomasa mikroba (mg), apparent degradable $(\mathrm{mg})$ dan true degradable (mg) dari pakan perlakuan secara in vitro pada inkubasi 48 jam

\begin{tabular}{clll}
\hline Pakan perlakuan & $\begin{array}{l}\text { Biomasa mikroba } \\
(\mathrm{mg})\end{array}$ & $\begin{array}{l}\text { Apparent degrada- } \\
\text { ble }(\mathrm{mg})\end{array}$ & $\begin{array}{l}\text { True degradable } \\
(\mathrm{mg})\end{array}$ \\
\hline $\mathrm{R}_{1}$ & $61,7 \pm 3,55^{\mathrm{bcd}}$ & $277 \pm 2,51$ & $339 \pm 0,89^{\mathrm{ab}}$ \\
$\mathrm{R}_{1-\mathrm{D}}$ & $50,2 \pm 3,71^{\mathrm{ab}}$ & $284 \pm 3,50$ & $334 \pm 0,90^{\mathrm{a}}$ \\
$\mathrm{R}_{2}$ & $57,9 \pm 5,20^{\mathrm{abcd}}$ & $288 \pm 4,34$ & $344 \pm 4,57^{\mathrm{b}}$ \\
$\mathrm{R}_{2-\mathrm{D}}$ & $55,5 \pm 10,11^{\mathrm{abc}}$ & $288 \pm 2,15$ & $338 \pm 1,95^{\mathrm{ab}}$ \\
$\mathrm{R}_{3}$ & $52,3 \pm 6,51^{\mathrm{ab}}$ & $289 \pm 0,92$ & $346 \pm 0,47^{\mathrm{b}}$ \\
$\mathrm{R}_{3-\mathrm{D}}$ & $46,0 \pm 1,68^{\mathrm{a}}$ & $298 \pm 1,57$ & $343 \pm 1,85^{\mathrm{b}}$ \\
\hline
\end{tabular}

Keterangan: ${ }^{\mathrm{a}-\mathrm{e}}$ Superskrip yang berbeda pada kolom yang sama menunjukkan perbedaan sangat nyata $(\mathrm{P}<0,01)$

Tabel 5. Konsentrasi $\mathrm{N}-\mathrm{NH}_{3}$ dari pakan perlakuan kombinasi secara in vitro masa inkubasi 4, 12 dan 24 jam

\begin{tabular}{cccc}
\hline \multirow{2}{*}{ Pakan perlakuan } & \multicolumn{3}{c}{ Konsentrasi $\mathrm{N}^{-N_{3}}(\mathrm{mg} / 100 \mathrm{ml})$ pada masa inkubasi } \\
\cline { 2 - 4 } & 4 jam & 12 jam & 24 jam \\
\hline $\mathrm{R}_{1}$ & $8,76 \pm 3,60$ & $8,92 \pm 3,19$ & $8,75 \pm 2,73$ \\
$\mathrm{R}_{1-\mathrm{D}}$ & $8,16 \pm 1,63$ & $8,29 \pm 2,61$ & $8,71 \pm 2,68$ \\
$\mathrm{R}_{2}$ & $7,90 \pm 1,05$ & $9,20 \pm 1,99$ & $8,61 \pm 1,75$ \\
$\mathrm{R}_{2-\mathrm{D}}$ & $7,17 \pm 2,21$ & $6,99 \pm 0,80$ & $8,48 \pm 1,85$ \\
$\mathrm{R}_{3}$ & $8,04 \pm 2,10$ & $8,65 \pm 2,34$ & $8,08 \pm 1,54$ \\
$\mathrm{R}_{3-\mathrm{D}}$ & $7,48 \pm 1,71$ & $8,29 \pm 2,61$ & $8,10 \pm 1,09$ \\
\hline
\end{tabular}

Pada Tabel 4. nilai produksi biomasa mikroba dan true degradable pada waktu inkubasi 48 jam dari berbagai perlakuan berbeda sangat nyata $(\mathrm{P}<0,01)$, sedangkan terhadap apparent degradable tidak nyata $(\mathrm{P}>0,05)$. Produksi biomasa mikroba mengindikasikan banyaknya mikroba rumen (bakteri, protozoa, jamur) yang berperan dalam mencerna pakan di dalam rumen. Produksi biomasa mikroba dan nilai true degradable yang tinggi pada pakan perlakuan $\mathrm{R}_{1}$ mengindikasikan pakan yang diinkubasi memiliki potensi mudah larut dan mudah didegradasi di dalam rumen.

Pada pakan $\mathrm{R}_{3-\mathrm{D}}$ produksi biomasa mikroba yang dihasilkan terrendah, diduga adanya penekanan populasi mikroba akibat adanya senyawa condensed tannin (CT) dan saponin dari daun dalam pakan konsentrat mengakibatkan hambatan aktivitas mikroba rumen sehingga degradasi pakan sumber protein menurun di dalam rumen. Hal ini menunjukkan indikasi yang positif, dengan harapan protein akan dapat tercerna dan terserap secara maksimal di usus halus sehingga produktivitas ternak meningkat.

Konsentrasi $\mathrm{NH}_{3}$ dalam rumen merupakan hasil degradasi protein oleh mikroba rumen. Dalam penelitian ini didapatkan

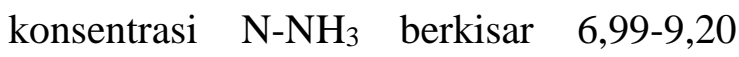
$\mathrm{mg} / 100 \mathrm{ml}$ pada inkubasi 4, 12 dan 24 jam diantara perlakuan tidak berbeda nyata $(\mathrm{P}>0,05)$.

Kadar $\mathrm{NH}_{3}$ untuk pertumbuhan optimal mikroba berkisar antara 5-8 mg/100ml atau 
rata-rata $5 \mathrm{mg} / 100 \mathrm{ml}$ cairan rumen. Kadar $\mathrm{NH}_{3}$ dari fermentasi daun tanaman pohon ini termasuk tinggi, karena kandungan PK pada daun tanaman pohon rata-rata tinggi (lebih dari 18\%). Semakin tinggi N maka makin banyak protein yang terdegradasi, konsentrasi $\mathrm{NH}_{3}$ yang tinggi di dalam rumen menunjukkan adanya degradasi protein yang besar (Mc Donald et al., 1988). Peranan $\mathrm{N}^{-\mathrm{NH}_{3}}$ dalam rumen untuk pertumbuhan mikroba sehingga fermentasi hijauan dapat dioptimalkan. Tingginya konsentrasi $\mathrm{NH}_{3}$ menyebabkan meningkatnya jumlah protein mikroba yang terbentuk sehingga populasi mikroba akan meningkat pula. Kekurangan $\mathrm{N}^{-\mathrm{NH}_{3}}$ akan menghambat aktivitas mikroba dalam proses metabolisme dan menghambat kecepatan pencernaan sehingga akan menurunkan ketersediaan energi.

Produksi $\mathrm{NH}_{3}$ sangat menentukan kecernaan serat oleh mikroba rumen terutama dalam menyediakan bakalan untuk síntesis enzim selulolitik. Produksi enzim selulolitik dipengaruhi oleh ketersediaan kadar $\mathrm{N}-\mathrm{NH}_{3}$ dalam rumen. Kadar $\mathrm{NH}_{3}$ yang tinggi dapat dijelaskan bahwa daun tanaman pohon yang mengandung senyawa saponin dan andrografolid diduga tidak memberi pengaruh terhadap penekanan bakteri (Camacho et al., 1993), sehingga diduga akan memacu aktivitas bakteri dalam menghidrolisis protein atau NPN menghasilkan $\mathrm{NH}_{3} . \mathrm{NH}_{3}$ yang dihasilkan akan dipergunakan sebagai material utama dalam sintesis protein mikroba asal bakteri (Satter and Roffler, 1975).

Memperhatikan hasil penelitian yaitu nilai kecernaan $\mathrm{BO}$ dan produk fermentasi secara in vitro (khususnya biomassa mikroba), maka direkomendasikan penggunaan pakan konsentrat protein $18 \%$ dengan memanfaatkan tepung daun gamal, kelor, randu dan sengon sebagai sumber protein murah pakan konsentrat ruminansia. Imbangan penggunaan pakan konsentrat 50\%: pakan hijauan $50 \%$ secara in vitro masih memerlukan pengujian lebih lanjut secara in vivo. Dimungkinkan bisa terjadi perubahan proporsi konsentrat: hijauan, karena formulasi pakan ditentukan oleh faktor ternak, faktor ketersediaan bahan pakan dan faktor ekonomis.

\section{KESIMPULAN}

Penggunaan daun tanaman sebagai bahan penyusun dalam pakan konsentrat dapat menghasilkan proses fermentasi normal. Suplementasi daun gamal, kelor, randu, dan sengon (1:1:1:1) sebanyak $20 \%$ dalam pakan konsentrat dengan PK 18\% menghasilkan fermentabilitas in vitro yang paling baik.

\section{DAFTAR PUSTAKA}

AOAC, 1990. Official Methods of Analysis of the Association of Analytical Chemist. $15^{\text {th }}$ ed. Association of Official Analytical Chemist. Arlington. VA. USA.

Blummel M., Steingas H. and Becker K., 1997. The relationship between in vitro gas production, in vitro microbial biomass yield and $15 \mathrm{~N}$ incorporation and its implications for the prediction of voluntary feed intake of roughages. Br J Nutr, 77(6) : 911-21.

Camacho A.N., M.A. Laredo, A. Cuesta, H. Anzola and J.C. Leon. 1993. Effect of Supplementation with a Tree Legume Forage. J. Livestoock Research for Rural Development, 5(2) : 59-73.

Cheeke, P.R. 2000. Actual and potential applications of Yucca schidigera and 
Quillaja saponaria saponins in human and animal nutrition. In Proceedings of the American Society of Animal Science, Indiapolis 10p. 1999. Retrieved 21 June, 2014, from http://www.asas.org/JAS/symposia/pro ceeding/0909.pd

Conway, E.J., 1957. Microdiffusion analysis and volumetric error. Crosby cockwood, London, UK

Hess, H.D., Tiemann, T.T., Noto, F., Carulla, J.E., Kreuzer, M., 2006. Strategic use of tannins as means to limit methane emission from ruminant livestock. International Congress Series 1293 : 164-167.

Holtshausen, L., Chaves, A.V., Beauchemin, K.A., McGinn,S.M,, McAllister,T.A., Odongo, N.E., Cheeke,P.R., and Benchaar,C. 2009. Feeding saponin-containing Yucca schidigera and Quillaja saponaria to decrease enteric methane production in dairy cows. $J$ Dairy Sci, 92(6):2809-21.

Jayanegara, A. dan Sofyan, A., 2008. Penentuan aktivitas biologis tannin beberapa hijauan secara in vitro menggunakan hohenheim gas test dengan polietilen glikol sebagai determinan. Med.Pet, 31(1) : 44-52.

Makkar, H.P.S, M. Blủmmel and K. Becker. 1995. Formation of Complexes Between Polyvinyl Pyrrolidone or Polyethylene Glycol and Tannins and Their Implication in Gas Production and True Digestibility in In vitro Techniques. Br J Nutr, 73(6) : 897-913.

Marhaeniyanto, E., Rusmiwari, S. dan Susanti, S., 2015. Pemanfaatan Daun Kelor Untuk Meningkatkan Produksi Ternak Kelinci New Zealand white. Jurnal Buana Sains, 15(2) : 119-126.
Maw N.N., K San Mu, A. Aung and M.T. Htun. 2006. Preliminary Report on Nutritive Value of Some Tree Foliages. Conference on International Agricultural Research for Development. October 11-13, 2006. University of Bonn. Myanmar.

McDonald, P., Erdwards, R.A., and Greenhalgh. J.F. D., 1988. Animal Nutrition $4^{\text {th }}$ Edition. Longhman Scientific and Technical. New York.

Muchlas, M., Kusmartono dan Marjuki. 2013. Pengaruh penambahan daun pohon terhadap kadar VFA dan kecernaan secara in-vitro ransum berbasis ketela pohon. Jurnal Ilmu-Ilmu Peternakan, 24 (2): 8-19.

Preston, T.R and R.A. Leng. 1987. Matching ruminant production system with available resources in the tropic and sub tropic. Armidale : Penambul Book.

Santoso B. 2005. Rumen fermentation characteristic and methanogharacteristic and methanogenesis in sheep fed silage based diet supplemen supplemented with Yucca schidilgera or Yucca schidilgera combined with nisin. Buletin of. Animal Science 28: 13-18.

Santoso, B dan B.Tj. Hariadi. 2007. Pengaruh Suplementasi Acacia mangium Will pada Pennisetum purpureum terhadap Karakteristik Fermentasi dan Produksi Gas $\mathrm{CH}_{4}$ in vitro. Med.Pet. 30(2) : 106-113.

Satter, L.D. and R.E. Rofller. 1975. Nitrogen Requirement and Utilization In Dairy Cattle. J. Dairy Sci, 58(8) : 1219-1237. 
Tillman, A. D., Hartadi, H., Reksohadiprodjo, S., Prawirokusumo, S. dan Lebdosoekojo, S., 1998. Ilmu Makanan Ternak Dasar. Gadjah Mada University Press. Yogyakarta.

Yitnosumarto, S. 1993. Percobaan, perancangan, analisis dan interpretasinya. Jakarta : Gramedia. 